\title{
Income-generating projects in rural communities: from theory to practice - a personal report
}

\author{
Anna-Marie Trollip and Elizabeth Boshoff
}

\begin{abstract}
OPSOMMING
Hierdie artikel berig oor die derde fase van ' $n$ studie vir die ontwikkeling van ' $n$ strategie vir die fasilitering van projekte wat poog om inkomste te genereer deur hoofsaaklik handvervaardigde goedere te produseer. Die artikel word ook aangebied as ' $\mathrm{n}$ voorbeeld vir deelnemende ontwikkeling (participatory development).
\end{abstract}

Die volgende doelstellings is vir hierdie fase van die studie gestel:

- Om die aannames van die aktiwiteitsmodel (Trollip, 2001) te toets en te verfyn vir toepassing in opleidingsprogramme vir inkomstegenereringsprojekte

- Om PLA-metodes (plan, leer en aksie-metodes) te toets om onafhanklikheid te bevorder en ontwikkeling te fasiliteer

- Om die rolspelers bewus te maak van probleme rondom inkomste-genereringsprojekte en hulle by die ontwikkeling van 'n ondersteuningstruktuur vir hierdie tipe projekte te betrek.

' $n$ Groep vroue in die omgewing van die Tswaing Krater-museum wat die behoefte uitgespreek het om inkomste te genereer deur kunshandwerkartikels te produseer, het aan die studie deelgeneem. Die omstandighede / konteks van dié vroue was tipies van baie agtergeblewe vroue in die noorde van Suid-Afrika. Hulle woon in ' $\mathrm{n}$ gebied sonder water en elektrisiteit, vervoer is beskikbaar maar duur, die gemiddelde geletterdheidsvlak is laag, en veral die ouer en minder geletterde vroue handhaaf nog in ' $n$ mate die gebruike van ' $n$ eie kultuur.

Tydens dialoog en waarnemeing is behoeftes bepaal. Met behulp van deelnemende waarnemingsmetodes soos dialoog, rolspel, selfleer in werklike situasies, nadoen en uittoets is die groep gefasiliteer om ' $n$ inkomste-generingsprojek aan te pak. Die aannames en aktiwitieite wat in Trollip (2001) se aktiwiteitsmodel uiteengesit is, het die studie gerig.

Hoewel die konteks van verskillende groepe of projekte waarskynlik sal verskil, blyk dit uit die sukses wat met hierdie projek behaal is dat die aktiwiteitsmodel toepassingsmoontlikhede het. Daar word beoog om die model in die volgende fase van die studie in 'n programraamwerk te formuleer. Die raamwerk kan dan aangewend word om soortgelyke studies te rig en as grondslag vir impakstudies te dien.

- Prof AM Trollip

Department of Consumer Science, University of Pretoria - Prof E Boshoff

Department of Consumer Science, University of Pretoria

\section{INTRODUCTION}

A study was conducted in three phases to develop an approach to skills training and group facilitation in order to generate income via crafts production:

- Identify and analyse the problems and needs of income-generating groups who are working with and without the assistance of a facilitator

- Join an existing successful group working with a facilitator to develop an understanding of group culture and group functioning

- Work on an experiential basis with a newly established group and apply insights gained during the first two phases to test and refine a strategy for providing assistance to income-generating community projects.

The findings of the first two phases of the study stimulated the development and refinement of an activity model (Trollip, 1997; Trollip, 2001). This article reports on the third phase of the study and reflects a participating insider's perspective.

Working with a newly established group, the specific aims for this phase of the study were to:

- apply, test and refine the premises of the activity model (Trollip, 2001) for application in training programmes targeting income-generating projects

- test the application of PLA methods to foster independence and facilitate development

- network as widely as possible to interest important role players in the dilemmas of income-generating groups and to involve them in the development of support structures for such groups.

\section{GETTING INVOLVED}

Three aspects of getting involved in the group who participated in the income-generating project will be discussed, namely background to the project, the participants, and how the facilitators joined forces with the participants.

\section{Background and introduction to the group}

Tswaing (meaning "place of salt") is a crater with a diameter of $1,4 \mathrm{~km}$ that was formed 200000 years ago when a meteorite landed about $50 \mathrm{~km}$ north of Pretoria in South Africa. The National Cultural History Museum of South Africa acquired 2000 ha surrounding this crater with a view to establishing an on-site living history museum. The involvement of Cultural Museum officials at the Tswaing Crater Museum 
sparked a partnership between the officials and the community in the surrounding area. This partnership was formed to support the interests of both parties.

The community formed several interest groups and requested the University of Pretoria (via museum officials) to help them develop the living cultural museum and the community. The then Department of Home Economics of the University of Pretoria became involved when two graduate students undertook a research project under the guidance of the head of the Department of Home Economics (Boshoff) to determine aspects of household resources management by women in one of the rural settlements (Mmotla) near the museum.

Contact was established with this group through a community leader who convened a meeting of older and younger women from Mmotla. This research aimed to discover aspects of the traditional way of life that were still practised by the older women, and to determine whether the younger women had any knowledge of these traditional aspects (eg using indigenous skills to produce utility items and crafts). It became clear during contact sessions that the women needed help to establish a project that would generate income. As a quid pro quo for participation in this research, the group was promised that the then Department of Home Economics would provide assistance if they wanted to proceed with the idea of initiating an income-generating project.

Following the initial request, Boshoff and Trollip (colleagues at the Department of Home Economics) again made contact with the community during the second half of the following year (1997). The same community leader provided assistance. During the first meeting with members of the community, a number of older and younger women expressed interest in producing crafts. Other planned projects included a baking project, and a donor had already supplied electrical equipment for this purpose. (The area received electricity four years later and the equipment was stolen before the project got off the ground.) Two women from the community were already involved in needlework lessons to the community and the community seemed inclined to develop.

The challenge of assisting the group was accepted against the background of experience gained during previous phases of the study (Trollip, 2001). The work was guided by an extensive study of the literature (eg authors such as Vroom (1964), McCleland \& Winter (1969), Blumberg \& Pringle (1982), Katzell \& Thompson (1990) and Robbins (1993)) influenced the approach as far as motivational theories were concerned. From a methodological viewpoint, various authors who advocated qualitative and ethnological approaches to research (Pelto, 1970; Geertz, 1973; Bogdan \& Taylor, 1975; Ferreira et al, 1988; Babbie, $1989)$ as well as authors in the field of participatory research (Rhaman, 1991; Theis \& Grady, 1991; Burkey, 1993; Mouton, 1996) were studied. The other guiding principle, namely cultural relativism, originated from a cultural dress background and acceptance of symbolic anthropological and humanistic principles (Lett, 1987).

Boshoff had extensive experience in community development work and had been involved in development projects in several communities in and around Pretoria since 1978. Under her guidance, students in the then Home Economics Extension courses had to undertake development projects to apply the principles of adult education and community development in real-life situations and different ethnic groups.

At the time of writing this report, Trollip was still involved in the project, but to a lesser extent (giving moral support, acting as an informal marketing agent and handling export orders). Boshoff provided valued assistance as co-facilitator during the first 18 months of the project's existence.

\section{The participants}

The participants in the group were typical of rural production groups. A few of the younger members were literate, and some of the older women knew how to make beaded and grass articles. Almost no one had marketing skills or had received business training or knew anything about product development. The group had no funds and no accommodation. The area had a poorly developed infrastructure with neither running water nor electricity. All the women needed income and were eager to participate in an income-generating project.

\section{The facilitators joining forces with the participants}

Acceptance of the facilitators by the group members was facilitated by the fact that most members knew Boshoff and had requested assistance. In building a relationship of trust, the facilitators had to work through the usual stages to be fully accepted by everybody. Several factors contributed to the ease with which the group took ownership of the project: The members wanted the project - it was not forced on them. Although not formally elected at the time, one person acted as the spokesperson. Other formal and more informal leaders (some with political motives) from the community formed part of the group. All of them already enjoyed the trust of the rest of the group and were willing to fulfil leadership positions and to take on the responsibility of running the project.

The facilitators tried not to leave the group in doubt about how they saw their role. It was made clear during the first meetings that only expertise - no funds - would be contributed. That eliminated "welfare" expectations and associations. It was stated repeatedly that the responsibility for continuation of the project was the group's. The simile of a tree was used to explain that the facilitators' involvement would eventually stop. The members were compared to the trunk, branches and roots of the tree and the facilitators to the leaves. 
The decision to produce hand-made crafts eliminated the problem of not having electricity and advanced technology for production. Hand-made crafts have a unique market niche and consequently do not have to compete with factory-produced articles in terms of price or quality. The older members were skilled bead workers and could still weave with grass. They were willing to teach the unskilled younger women. The facilitators could therefore proceed on this basis and focus on developing marketable products.

\section{FACILITATING THE DEVELOPMENT PROCESS}

The basic principles of Trollip's activity model (2001) were applied to get the project off the ground, namely developing abilities, cultural involvement and networking. Before these principles could be implemented, however, certain groundwork (eg a needs analysis) had to be done. It is difficult to present the different elements of the process in a particular chronological order as several issues had to be addressed at the same time. These issues included the following:

- A need analysis

- Establishing an organisational structure

- Establishing a group identity

- Identifying products and developing marketable products

- Skills development and training

- Identifying marketing outlets.

It is also difficult to indicate how much time was or should be spent on each issue. It would probably depend on the context and composition of each group, the extent of the members' literacy, leadership potential, and so on.

The facilitators and group members met one morning per week for at least five months. Time was spent on discussing needs and challenges and on planning strategies and solutions. In the following year one of the facilitators visited the women about once every two weeks. The group members continued to meet at least once per week. (Later, after they acquired a building, and while they were working on large orders, the group laid down a rule that everyone had to work together in the workshop every day. The members could finish their household tasks before they went to the workshop. Payment depended on the number of acceptable items a person produced. Items that could be sold at craft markets could be worked on at home, because the group members then used their personal stock.)

\section{Needs analysis}

Needs were listed and analysed during the weekly discussions. Not all needs were listed at once. Some aspects could only be identified as needs after the members have had some marketing experience. As stated in the literature on needs (Wasserman \& Kriel, 1997:29) and experience (Trollip, 2001), there were also needs to which the group members were not sensitive or of which they were not aware. These needs included product knowledge, culture (especially in terms of time), tastes in the target markets, and almost every aspect related to marketing.

The group members were able to list needs that were important to establishing the project, namely funding, accommodation and project management. The most immediate needs were addressed first, for example project structuring, funding, product development, selling skills and marketing outlets. Some needs could only be addressed over time, such as accommodation. New needs developed as the group developed, for example participation in national and international trade shows.

The facilitators faced a number of challenges (stemming from needs) of which they were not aware or did not expect to be part of the facilitation process. Some of these needs were related to context problems (the project being in an underdeveloped area). Marketing outlets were in urban areas and stock had to be transported to these markets. Due to the volume of such stock, it was impossible to transport the articles between the project premises and each urban market twice or more often every month. The stock therefore had to be stored in an urban area, between markets. Producers who sold at craft markets had to exhibit their goods attractively and in all weather conditions. Solutions for these and many other problems had to be found.

\section{Structuring the project}

Project structuring included selecting a committee, name and logo, a vision and goals, and developing managerial skills (eg stock control, financial management). The officials had to be sensitised to their respective functions and tasks. A constitution had to be drawn up. Still other matters had to be addressed, for example a membership fee and contributions to project funds to cover marketing costs and termination of membership.

The funding problem was addressed in the following manner:

The project retained twenty per cent of the selling price of each item to establish a project fund that would cover transport and other marketing expenses. The accumulated funds eventually enabled the project to accept corporate orders and buy stock in bulk. The bigger income enabled the women to open a bank account. When the project eventually applied for donor funds, a constitution, a membership list and a bank account were prerequisites. This project applied for and received funds to buy a building for use as a workshop cum craft shop.

One of the goals of the project was to help each other in times of need. The members were allowed to borrow small amounts of money interest-free to help them through personal crises such as illness and funerals. The member paid back the loan when she could afford to do so. 


\section{Establishing a group identity}

The members first had to commit themselves to the principle of forming a group with a particular group structure, vision, goals (short and long-term) and plans to realise these goals. A definite commitment was required of each member. Although some of them were very reserved in the beginning, all needed the income. They saw the project as a means to this end. The principle of establishing the project was therefore accepted enthusiastically and only one member has left the group since its inception. The members have been very protective of their project and only a few new members were allowed to join over the years. (This has important implications for the generally accepted idea among developers that such projects have a snowball reaction!)

From Trollip's previous experience of the marketing advantages of a recognisable identity, the members were encouraged to choose a name and logo for their project. Naming the project had several favorable spin-offs, some of which were foreseen and others unexpected. The indigenous name Tswaraganang this group chose meant "working together" and the logo consists of two hands joined in a handshake. The name and logo immediately provided a group or corporate identity, which promoted a spirit of cooperation. The members assumed responsibility and ownership for the project. The group became known to the outside world, and this enhanced promotion. Opening a bank account in this name was not just an economic milestone, but also contributed to formalisation of the project's identity.

The facilitators sensitised the members to presenting their products neatly and attractively packaged to promote a perception of quality among customers (a modern-world buying criterion). The members were also sensitised to the need for a label, and the facilitators helped them to develop a label. The label carries the name, the logo and a brief summary of the vision and goals of the project, contact telephone numbers (for orders!), and the name of the producer to personalise the item for the buyer. Tourists are especially interested in this information as it contributes to the pleasant memories a tourist hopes to take home after travelling in a foreign country. The fact that a project member can be identified through her product has at least two important results: she experiences pride in her work, and as the producer has become identifiable, it serves as motivation to deliver items of an even better quality.

A product philosophy was formulated to establish an identifiable character for these products. This also contributed to strengthening the group identity.

\section{Identifying and developing suitable and sellable products}

Existing skills were used as a point of departure to identify products for production. Availability and cost and sources of raw materials were investigated.
Uniqueness and competitiveness were considered, and included pricing and the extent of the product lines of competitors.

Production of a particular item did not begin until it was established by means of prototypes that the item had marketing potential. (This aspect is treated more comprehensively under the heading, "Application of PLA methods".)

\section{Developing skills}

One basic assumption of participatory development is that community members possess knowledge and skills that can be used in the development process. The credo formulated by James Yen in 1920 (in Burkey, 1993) is widely accepted. It inter alia entails that development facilitators plan and work with the people, start with what they (the community) know, build on what they have, teach by showing and learn by doing.

The following strategy was applied in this project in an effort to meet the above:

- Older group members taught the traditional skills of beading and grass weaving and plaiting to the younger members.

- The more literate members were chosen (by the other members) to manage the project and to sell the products. Those who had acquired experience (eg selling skills) in certain areas taught the inexperienced women. The facilitators were therefore not involved in teaching all the skills to all the group members. Nor was it necessary for all the members to learn all the skills to cooperate successfully. This saved time and energy, and individual members did what they could do best, that is job diversification.

- Where training of the less literate members was required, less formal methods (eg role playing and experiential learning) were employed.

A measure of formal training had to take place, however (eg teaching one of the members some basic bookkeeping skills). Skills were also acquired by members of the group by attending courses offered by other training groups in the community. In this way two members attended various courses, for example an administrative course presented by the support organisation to help them run the project. A stockkeeping system that the members could apply was developed by trial and error (learning by doing!).

Teaching by way of PLA methods was a continuing process. Selling skills were of the first skills taught (discussed in more detail under the heading, "Implementation of PLA principles").

The abilities and skills listed in Trollip's (1997) activity model cover a range of skills and abilities that had to be developed and transferred to this group. 


\section{Identifying marketing outlets}

It is of no use to have a product and not know where to market it. Identifying marketing opportunities was high on the list of challenges to be addressed. Craft shops, flea markets, craft and conference markets were listed as possible outlets. One craft shop manager provided valuable assistance in testing the marketability of products, but it soon became evident that this was not a viable outlet. In selling to shops, the producer has to be willing to accept a lower profit margin as the shop also needs to make a profit after its overheads have been paid. This means that the prices offered become so low that it is hardly worth the effort to produce the article. Most craft items are small and the profit low. Only producers who have access to beads at wholesale prices can sell in bulk to shops. Selling directly to the customer at for example craft and conference markets, eliminates the third party.

The women in this project soon realised that the customers in the various markets differed slightly as far as taste and needs were concerned. A different selection of goods sold well at each of these markets. Selling on these markets also had the advantage of bringing the women in contact with their customers and this proved to be valuable in terms of recognition of the group. Contact at markets often resulted in large orders. The customers also proved to be a good source of new product ideas.

\section{LEARNING TO ADAPT TO ANOTHER CULTURE}

One involvement area identified in Trollip's (1997) activity model is that mutual cultural involvement is important in facilitating motivation and goal setting. The group members were exposed to their target markets whenever possible to gain insight into the market's culture, tastes and preferences.

- Members with the necessary literacy skills took turns to market their products at craft and conference markets. This afforded opportunities to interact with the customers and to learn to understand their tastes. Conference orders brought the importance of timely delivery and the standardisation of quality home.

- Members took part in development forums where they could share ideas and experiences with the members of other development groups.

- Members participated in trade shows, which gave them an idea of the competitiveness of the open market.

- As their products gained recognition, more individuals and groups visited the project's premises. These included two members of the British Bead Workers' Association who spent a week with the project. In return, one of the members was invited to visit Britain as a guest of the British Bead Workers' Association.

Both facilitators were sensitive to the culture of the members, they tried to treat everyone with respect and not to offend the more traditionally minded older members by their way of dressing. It is a known fact that time is not perceived similarly by different ethnic groups in South Africa. On the one hand the facilitators had to be patient, but at the same time they had to sensitise the group members to the value a modern/ Western society places on economic time usage.

\section{USING PLA PRINCIPLES}

Together the members and facilitators applied the three major PLA principles, namely participation, learning/planning and action. Typical participatory methods, especially dialogue, role-play and real-life experiences were applied. The facilitators tried to be reticent, allowing the women to voice their needs and opinions. Meetings took place weekly on one morning per week over a six-month period to discuss and develop strategies. Discussions (the process of dialogue to convert concepts into action) were followed by action, and action by reflection in a continuous cycle of dialogue, action and reflection. The following example of identifying marketable craft products illustrates the cycle:

Dialogue opened with a simple question or statement, for example "Let's decide on the products you can make". The group members would then be given ample opportunity to discuss ideas. Those who hesitated to participate were asked for their opinions. No contributions should be ignored. Related aspects such as advantages and disadvantages of producing a particular article, the tastes and preferences of the target market, previous experience and so one were discussion topics. Gradually all ideas were sorted out.

The members of this project usually tried to complete examples to bring to the next meeting. These examples were then analysed in terms of aspects such as aesthetic and functional qualities. Suggestions for improving the quality of workmanship were discussed. One of the facilitators usually took these examples and showed them to potential buyers such as craft shop owners. Marketability was widely discussed with colleagues and prospective customers.

The facilitators tried to sell as many of the products as possible, believing that success is a strong motivational factor. They reported back at the following meeting, subtly prompting the members to identify solutions to rendering the products more marketable. Sales were analysed, lists were compiled of articles that sold immediately and those that were slow sellers or did not sell at all. These articles were then again discussed in the dialogue cycle. Nothing was produced in big quantities until a decision had been reached about its marketing potential.

The following example illustrates the role-play and a real-life experience. The project had an opportunity to take part in a craft market. The facilitators accompanied the members who were appointed to sell, but did not get involved in the marketing effort. Very few 
items were sold, not because the products were unacceptable but because the sellers were inexperienced in presenting their articles to customers and had no selling skills. The sellers' own cultural norms prescribe that a person has to avoid eye contact to show respect. To a customer from another culture this can be interpreted as disinterest in selling anything. The women also left their exhibits to attend a dance performance that was part of the market. (During their absence at the dance performance, one of the facilitators noticed that the exhibit has been left unattended. She went to the exhibit to keep an eye on the products and within a short period sold a few products to customers who only looked mildly interested in the exhibit!) From a Western/modern perspective, such behavior (leaving an exhibit unattended) would be criticised. However, it has to be kept in mind that people who live in rural areas without money almost never have an opportunity to attend such an occasion.

This first marketing effort was analysed in a dialogue cycle, followed by role-play to practise selling skills. The facilitators helped them at a next market to teach by example. The group members subsequently marketed their products with great success.

The above and other PLA methods were used to plan and conduct every aspect of the project:

- Electing a committee

- Formulating a vision and goals for the project

- Selecting a name and logo for the project

- Identifying existing skills of group members

- Identifying marketable products

- Formulating a product philosophy

- Generating funds to produce crafts on a large scale

- Identifying role players in the community to help with the accommodation problem.

\section{SUCCESSES}

At the date of the publication of this article the project has been in existence for just over four years and has been very successful. Tswaraganang for example: .

- developed the ability to operate independently

- established a legal trust to ensure continuation of the project

- opened and operates a banking account and administers its own financial affairs

- developed and uses an efficient stock-keeping system

- produces high-quality beaded articles

- has a reputation for delivering goods on due dates

- owns a building consisting of a shop and working room

- has some export contracts

- is attending national and international trade shows

- regularly participates in exclusive craft markets

- is recognised and respected in South African society.

Each member has contributed to the project's success by doing what she can do to the best of her ability, ei- ther taking part actively in marketing the articles or in managing the project or producing articles. Visions for the future include the extension of national and international markets, renovation of the building and developing a cultural centre on the premises.

\section{SPIN-OFFS}

The facilitators regularly took photographs - during meetings, at markets, of products, at social functions (eg the Christmas party). While some of these photos were presented to the members, it became clear to the facilitators that some of the women had poor eyesight. One of the facilitators contacted a sympathetic pharmacist who made glasses available to the members of Tswaraganang at cost. It was a joyous day when they could all see clearly! They never realised how impaired their eyesight had become with age.

When Tswaraganang recently applied for a second development grant, all the members had to sign the contract. This again caused the management of Tswaraganang to realise that many of the members were illiterate. Adult basic education classes were organised in the building that belongs to Tswaraganang. The members regularly turn up with their glasses for these classes and nobody is ever late!

\section{CONCLUSION}

Although the project has been very successful, everything did not always go smoothly. The same conflicts as those described for the second phase of the study occurred. At one stage political conflict brought the project's activities to a standstill for months. Not all decisions always proved to have been the best decisions, and some resulted in expensive learning experiences. The incomes of some of the members are still just above marginal.

To summarise the process from a PLA point of view, as discussed by Wetmore and Theron (1998):

The project members had to change their behaviour patterns and attitudes and had to be ready and willing to

- accept change

- to take ownership of the project

- accept new horizons.

The facilitators had to be willing to:

- unlearn

- listen

- accept dramatic perception changes

- as well as the fact that they were not the only experts.

Together the members and the facilitators accomplished a

- change in awareness, motivation and behaviour

- change in interpersonal relations

- change in group relations in society. 
With regard to the first aim for this phase of the study, namely to apply, test and refine Trollip's activity model, it was the experience that the model provided a basis on which to work. It supplied a framework that could be used as a checklist to plan, initiate and control the project. This model has to be formulated in programme format to expand its applicability.

From a participatory perspective, there has been ongoing debate among developers about the formulation of so-called primary and secondary development aims (Wasserman \& Kriel, 1997:61). These authors argue that participation implies that members should formulate their own aims and that these aims had to be classified as secondary aims. The community members were inclined to identify more concrete aims and would seldom define primary aims such as developing self-confidence and dignity. However, it is true to state that the more abstract aims were achieved in the process of achieving the secondary, more concrete aims. It is achievement of these aims that makes the facilitator's involvement in community development a worthwhile experience. The model of Wetmore and Theron (1998) aptly relates participation to important development values (Figure 1).

The outcomes of this project truly prove that participation in their own development can realise the development values summarised in the model. Self-help in this manner leads to self-reliant development.

The aim to network as widely as possible to interest role players (also from government) in providing a support system for groups similar to the one discussed above was only partly realised. There is fairly general consensus that such a support system is necessary, but there is also reluctance to take responsibility for planning and coordinating such a system. Many role players (including part-time and unofficial facilitators) are involved in wonderful projects, but they are working in isolation. Knowledge, experience and resources are not shared. Each facilitator therefore has to invent the wheel again. The goalposts of successful projects may shift so much during development that it moves outside the scope and ability of a particular developer to provide optimal assistance.

Despite the commitment of the South African government and the involvement of numerous organisations and institutions in community development programmes, and despite the considerable amounts of money invested to alleviate poverty in South Africa, the position of the poor in rural South Africa has not changed much for the better during the past decade. This is partly also due to the fact that the outcomes of development projects are not effectively monitored.

New goalposts were set for this particular project, namely to formulate and expand the activity model to programme format to serve as a guideline for similar community development projects, and to design an impact evaluation study.

\section{REFERENCES}

BABBIE, E. 1989. The practice of social research. $5^{\text {th }}$ ed. Belmont, Cal. Wadsworth.

BLUMBERG, M \& PRINGLE, CD. 1982. The missing opportunity in organizational research: some implications for a theory of work performance. Academy of Management Re-

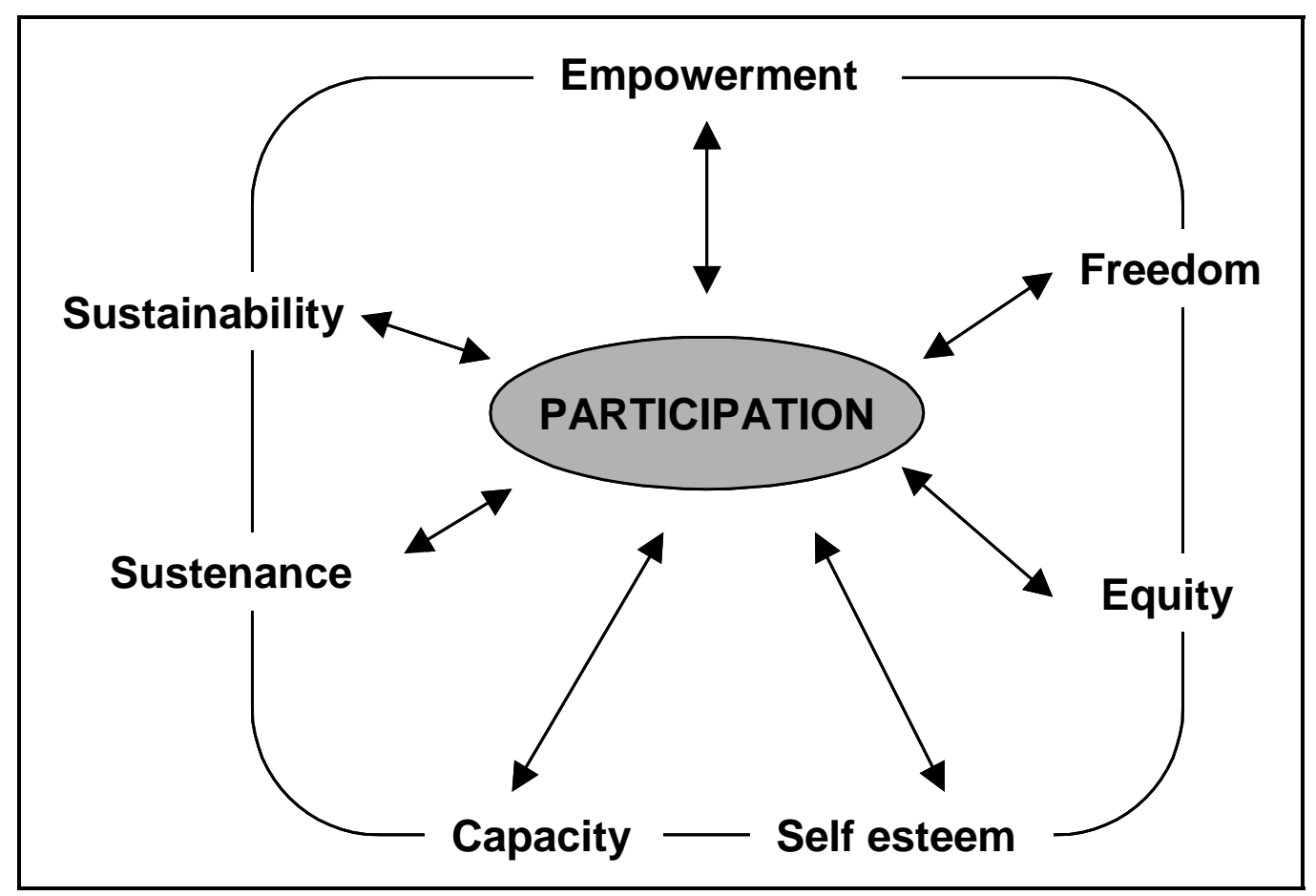

FIGURE 1: PARTICIPATION RELATED TO DEVELOPMENT VALUES (Wetmore \& Theron, 1998:27) 
view Oct:565.

BOGDAN, R \& TAYLOR, SJ. 1975. Introduction to qualitative research methods. A phenomenological approach to the social sciences. New York. Wiley.

BURKEY, S. 1993. People first: a guide to self-reliant participatory rural development. London. Zed.

FERREIRA, M, MOUTON, G, SCHURINK, EM \& SCHURINK, WJ. 1988. Inleiding tot kwalitatiewe metodes. Pretoria. Raad vir Geesteswetenskaplike Navorsing.

GEERTZ, C. 1973. The interpretation of cultures. London. Hutchinson.

KATZELL, RA \& THOMPSON, DE. 1990. Work motivation. Theory and practice. American Psychology 45(2):144-153.

LETT, J. 1987. The human enterprise. A critical introduction to anthropological theory. London. Westview Press.

MALAN, JS. 1988. The cosmological factor in development programmes. South African Journal of Ethnology 11(2):6166.

MCCLELAND, DC \& WINTER, DG. 1969. Motivating economic achievement. New York. Free Press.

MOUTON, J. 1996. Theory, metatheory and methodology in development studies. In Coetzee, LK \& Graaff, J (eds). Reconstruction and development and people. Johannesburg. International Thomson.

PELTO, PJ. 1970. Anthropological research: the structure of inquiry. New York. Harper \& Row.

RAHMAN, MA. 1991. The rhetorical standpoint of PAR. In
Fals-Borda, O \& Rahman, MA (eds). 1991. Action and knowledge: breaking the monopoly with participatory action research. New York. Apex.

ROBBINS, SP. 1993. Organizational behavior. Concepts, controversies and applications. $6^{\text {th }}$ ed. Englewood Cliffs, NJ. Prentice-Hall.

THEIS, J \& GRADY, HM. 1991. Participatory rapid appraisal for community development. A training manual based on experiences in the Middle East and North Africa. London. International Institute for Environment and Development.

TROLLIP, AM. 1997. Towards developing a model for the empowerment of rural South African women. Journal of Dietetics and Home Economics 25(1):2-10, 18.

TROLLIP, AM. 2001. The development of a strategy for the facilitation of income-generating projects in rural communities: an insider account. Journal of Family Ecology and Consumer Sciences 29:45-51.

VROOM, VH. 1964. Work and motivation. New York. Wiley.

WASSERMAN, I \& KRIEL, JD. 1997. Facts and fallacies. Perspectives on community development. Pretoria. Wasserman \& Kriel.

WETMORE, SB \& THERON, F. 1998. Community development and research: p;articipatory learning and action - a development strategy in itself. Development Southern Africa 15(1):29-54. 